\title{
PENGARUH OBESITAS TERHADAP INFERTILITAS PADA WANITA PASANGAN USIA SUBUR DI RUMAH SAKIT AWAL BROS PEKANBARU
}

\author{
SRI ANGGRAINI, ZUCHRAH HASAN*, AFRIDA** \\ *Dosen Jurusan Kebidanan Poltekkes Kemenkes Riau, \\ **Mahasiswa Jurusan Kebidanan Poltekkes Kemenkes Riau
}

\begin{abstract}
ABSTRAK
Sekitar 15 juta wanita pasangan usia subur di Indonesia pada akhir tahun 2009 mengalami Infertilitas. dengan demikian 1,5 hingga 2 juta pasangan usia subur mengalami infertilitas dan obesitas yang telah lama dikaitkan dengan masalah ketidaksuburan (infertilitas) . Studi pendahuluan di Poliklinik Kebidanan RS Awal Bros Pekanbaru pada bulan Desember tahun 2013, terdapat kunjungan wanita pasangan usia subur yang mengalami infertilitas, meningkat $25 \%$ ( 119 orang ) dari tahun sebelumnya . Penelitian ini bertujuan untuk mengetahui hubungan obesitas dengan infertilitas pada wanita pasangan usia subur.

Jenis penelitian inikuantitatif dengan desain korelasi yang dilakukan pada bulan Januari 2014 di poliklinik kebidanan RS.Awal Bross. Populasi pada penelitian ini adalah wanita pasangan usia subur berumur 20-35 tahun pada tahun 2013 sebanyak 155 orang dengan teknik pengambilan sampel total populasi. Data diolah secara manual.kemudian di analisis secara univariat dan bivariat menggunakan uji statistik chi square dengan $\mathrm{df}=1, \alpha: 0,05$

Hasil penelitian menunjukkan bahwa terdapat wanita pasangan usia subur dengan obesitas 105 orang $(67,74 \%)$, dan yang mengalami infertil 85 orang ( $80,95 \%)$. Analisis Bivariat didapatkan ada hubungan antara obesitas dengan infertilitas dengan $\mathrm{x}^{2}$ hitung $16.07>$ dari $\mathrm{x}^{2}$ table 3.84 .

Hasil penelitian ini dapat menjadi masukan tentang wanita obesitas yang cenderug mengalami infertilitas, agar peningkatkan pelaksanaan program penurunan berat badan menjadi perhatian yang serius ,sebagai salah satu upaya penurunan kejadian infertilitas pada wanita pasangan usia subur.
\end{abstract}

Kata Kunci : Obesitas, Infertilitas

\section{PENDAHULUAN}

Insiden infertilitas meningkat sekitar $100 \%$ selama 20 tahun terakhir di negara-negara maju dan Infertilitas menyebabkan peningkatan $10 \%$ - $20 \%$ dari semua kunjungan di bagian gynekologi rumah sakit. Penilaian yang cermat harus dapat mengenali kemungkinan penyebab 85\%-90\% kasus infertilitas (Benson and Pernoll's, 2009). Pada akhir tahun 2009 di Indonesia sekitar
15 juta pasangan usia subur mengalami Infertilitas, dengan demikian 1,5 hingga 2 juta pasangan mengalami infertiitas , Untuk mengetahui adanya masalah infertilitas diperlukan deteksi dini dan dibutuhkan penatalaksanaan pengobatan yang mendekati paripurna.(Wiweko B, 2010)

Obesitas telah lama dikaitkan dengan masalah ketidaksuburan (infertilitas). Sebuah penelitian yang 
dıpublikasikan di Journal Of Clinical Endocrinologyi \& Metabolism (JCEM) 2009, telah lama menemukan hubungan antara kedua faktor tersebut. Studi ini melibatkan 96 perempuan. Mereka dibagi secara seimbang ke dalam 3 kelompok sesuai dengan Body Massa Indeks (Robker,et al .2009). Penelitian menunjukkan bahwa wanita dengan berat badan lebih, mungkin akan sulit hamil. Kelebihan berat badan juga akan mempengaruhi kemampuan pria untuk memproduksi sperma, sementara wanita berat badan berlebih bisa mengganggu proses pembuahan, kehamilan, dan kelahiran (Charlish and Davies, 2005)

Pada tahun 2013 kunjungan pasangan infertile di Rumah sakit Awal Bros berjumlah 119 orang . Wawancara dengan 15 ( lima belas ) orang wanita, pasien poliklinik kebidanan, terdapat 8 orang dengan obesitas, diantaranya 5( lima ) orang mengalami infertilitas, peneliti ingin mengetahui hubungan obesitas dengan infertilitas pada wanita pasangan usia subur di Rumah sakit Awal Bros Pekanbaru tahun 2013.

\section{Rumusan Masalah}

Masalah yang ditemukan, adanya wanita pasangan usia subur yang mengalami obesitas dan cenderung mengalami infertilitas dan diduga " Ada Hubungan Obesitas dengan Infertilitas pada wanita pasangan Usia Subur .

\section{Tinjauan Pustaka}

Obesitas adalah kelebihan berat badan sebagai akibat dari penimbunan lemak tubuh yang berlebihan.Setiap orang memerlukan sejumlah lemak tubuh untuk menyimpan energi, sebagai penyekat panas, penyerap guncangan dan fungsi lainnya (Rocky, 2008).

Berbagai macam defenisi obesitas telah diketahui masyarakat. Pada umumnya, obesitas dapat dilihat secara fisik, tetapi dengan menggunakan hitungan tertentu terhadap Body Mass Index atau BMI dapat dipakai untuk menentukan seseorang tersebut mengalami obesitas atau tidak.(Misradiarly, 2007)

Rumus BMI itu sendiri sangat sederhana yaitu Berat Badan $(\mathrm{Kg}) /$ Tinggi Badan pangkat dua $\left(\mathrm{m}^{2}\right)$. Seseorang yang dikatakan BB normal dari rumus BMI yaitu klasifikasinya $20-24,9 \mathrm{~kg} / \mathrm{m}^{2}$, bila rentang $25-29,9 \mathrm{~kg} / \mathrm{m}^{2}$ dikatakan berat badan berlebih (over weight), dan yang dikatakan Obesitas bila rentangnya $30-39,9 \mathrm{~kg} / \mathrm{m}^{2}$.(Fraser and Cooper 2009)

Obesitas ada yang bersifat exogenous, yaitu konsumsi energi yang berlebihan, dan penyebab endogenous yang berarti adanya gangguan metabolik di dalam tubuh. Misalnya, adanya tumor pada hipotalamus sehingga si penderita mengalami hiperphalgia atau nafsu makan berlebihan.Hereditas (keturunan) menjadi salah satu faktor penyebab obesitas.Peluang seorang anak mengalami obesitas adalah 10 $\%$ meskipun bobot orang tua termasuk dalam kategori normal.Bila salah satu orang tua obes peluangnya menjadi $40 \%$, dan atau kalau kedua orang tua obes peluang si anak meningkat sebesar 80\% (Khomsan, 2004).

Gen merupakan faktor penting dalam berbagai kasus obesitas, tetapi lingkungan seseorang juga memegang peranan yang cukup berarti. Lingkungan ini termasuk 
perilaku/pola gaya hidup (misalnya apa yang

dimakan dan berapa kali seseorang makan serta bagaimana aktifitasnya). Seseorang tentu saja tidak dapat mengubah pola genetiknya, tetapi dia dapat mengubah pola makan dan aktifitasnya (Rocky, 2008)

Batasan berat badan normal orang dewasa ditentukan berdasarkan nilai Body Mass Index ( BMI).Di Indonesia istilah Body Mass Index diterjemahkan menjadi Indeks Massa Tubuh (IMT). IMT merupakan alat yang sederhana untuk memantau status gizi orang dewasa khususnya yang berkaitan dengan kekurangan dan kelebihan berat badan, maka mempertahankan berat badan normal memungkinkan seseorang dapat mencapai usia harapan hidup lebih panjang.

Perhitungan Indeks Massa Tubuh

IMT $=\frac{\text { Berat badan/Tinggi badan }(\mathrm{m}) \times \text { tinggi }}{\text { badan }(\mathrm{m})}$
Atau
Berat badan (dalam kilogram) dibagi kuadrat
tinqqi badan (dalam meter)

(Supariasa, et al .2002)

Rentang yang diharapkan atau rentang sehat adalah antara 20 dan 24,9. Kategori berat badan kurang, berlebihan, dan obesitas dapat menyebabkan bahaya kesehatan jangka panjang.

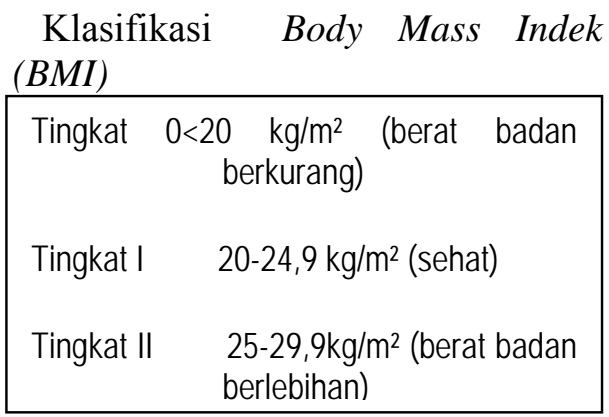

(Fraser and Cooper 2009)

Dasar terapi dan prevensi penyakit obesitas adalah memperhatikan keseimbangan antara energi yang dikonsumsi dan energi yang dipergunakan (expenditure).Jadi konsumsi energi harus dikurangi dan kegiatan otot ditinggikan, agar kelebihan jaringan lemak sebagai bentuk timbunan energi menjadi kurang. Pengurangan berat badan ini harus dilakukan secara berangsur, jangan terlalu drastis, karena akan memberikan gejalagejala sampingan yang merugikan.

Sebenarnya terapi obesitas tidaklah mudah seperti dikatakan, karena banyak faktor yang berpengaruh, selain keseimbangan antara energi yang dikonsumsi dengan yang diperlukan.Banyak penderita penyakit obesitas tidak berhasil menurunkan berat badannya, atau kalau berhasil, tidak secara permanen, tetapi dalam waktu relatif singkat berat badannya meningkat kembali, bahkan lebih tinggi dari sebelum upaya pengobatan.Upaya terapi penyakit obesitas, sebaiknya dilakukan dibawah petunjuk dan pengawasan seorang dokter ahli (Sediaoetama, 2004).

\section{INFERTILITAS}

Infertilitas

adalah

ketidakmampuan untuk hamil setelah 12 bulan hubungan seksual yang sering tanpa kontrasepsi ( Norwitz and Schorge 2006), dibedakan menjadi dua, yaitu primer dan sekunder.

Infertilitas primer : bila belum pernah hamil sama sekali.

Infertilitas sekunder : bila sudah pernah hamil / punya anak dan sekarang berusaha untuk hamil 
selama 12 bulan tanpa proteksi (Dewata, et al .2008).

Di Indonesia angka kejadian perempuan infertilitas $15 \%$ pada usia 30-34 tahun.

Infertilitas pada istri sekitar 60$75 \%$ yang disebabkan oleh berbagai faktor yaitu: vagina 1-3\%, serviks 6$10 \%$, uterus $4-5 \%$, tuba falopi $75-$ $85 \%$, ovarium $5-10 \%$ dan peritoneum 5-10\% (Manuaba, 2004).

1. Masalah vagina

Kemampuan menyampaikan air mani ke dalam vagina sekitar serviks perlu untuk fertilitas. Masalah vagina yang dapat menghambat penyampaian ini ialah adalah sumbatan atau peradangan. Sumbatan psikogen disebut vaginismus atau disparenia, sedangkan sumbatan anatomik dapat karena bawaan atau perolehan.Vaginitis karena kandida albikans atau trikomonas vaginalis hebat dapat merupakan masalah, bukan karena anti spermisidanya, melainkan anti sanggamanya.

\section{Masalah serviks}

Walaupun servik merupakan bagian uterus, namun artinya dalam reproduksi manusia baru diakui pada abad kesembilan belas. Sims pada tahun 1968 adalah orang pertama yang menghubungkan serviks dengan infertilitas.Infertilitas yang berhubungan dengan faktor serviks dapat disebabkan oleh sumbatan kanalis servikalis, lendir serviks yang abnormal, malposisi dari serviks, atau kombinasinya.Terdapat berbagai kelainan anatomi serviks yang dapat berperan dalam infertilitas, yaitu cacat bawaan (atresia), polip serviks, stenosis akibat trauma, peradangan (servisitis menahun), sinekia (biasanya bersamaan dengan sinekia intrauterin) setelah konisasi, dan inseminasi yang tidak adekuat.

2) Masalah uterus
Spermatozoa dapat ditemukan dalam tuba falopii manusia secepat 5 menit setelah inseminasi. Dibandingkan dengan besar spermatozoa dan jarak yang harus ditempuhnya, kiranya tidak mungkin migrasi spermatozoa berlansung hanya karena gerakannya sendiri.Tidak disangkal, kontraksi vagina dan uterus memegang peranan penting dalam transportasi spermatozoa ini. Pada manusia, oksitosin tidak berpengaruh terhadap uterus yang tidak hamil akan tetapi prostaglandin dalam air mani dapat membuat uterus berkontraksi secara ritmik. Ternyata, prostaglandinlah yang memegang peranan penting dalam transportasi spermatozoa ke dalam uterus dan melewati penyempitan pada batas uterus dengan tuba itu.Ternyata pula, uterus sangat sensitif terhadap prostaglandin pada akhir fase proliferasi dan permulaan sekresi. Dengan demikian, kurangnya prostaglandin dalam air mani dapat merupakan masalah infertilitas. Masalah lain yang dapat mengganggu transportasi spermatozoa melalui uterus ialah kavum uteri karena sinekia, mioma, atau polip; peradangan endometrium, dan gangguan konstraksi uterus. Kelainan-kelainan tersebut dapat mengganggu dalam hal implantasi, pertumbuhan intrauterine, dan nutrisi serta oksigenisasi janin.

3) Masalah tuba

Frekuensi faktor tuba dalam infertilitas sangat bergantung pada populasi yang diselidik.Peranan faktor tuba yang masuk akal ialah 25-50\%.Dengan demikian, dapat dikatakan faktor tuba paling sering ditemukan dalam masalah infertilitas.Oleh karena itulah, penilaian patensi tuba dianggap 
sebagai salah satu pemeriksaan terpenting dalam pengelolaan infertilitas.

\section{4) Masalah ovarium}

Kehamilan tidak mungkin terjadi bila pihak wanita tidak mampu memproduksi sel telur. Sebelum mencapai usia 18 tahun dan sesudah 38 tahun, ovulasi (produksi sel telur) terjadi secara tidak teratur. Tetapi diantara umur itu, pada umumnya ovulasi terjadi setiap bulan.Ovulasi yang jarang terjadipun dapat menyebabkan infertilitas.

(Prawirohardjo, 2007)

Anamnesis / pemeriksaan awal :

a. Umur

b. Riwayat penyakit radang panggul

c. Penggunaan AKDR

d. Pola haid

e. Pertumbuhan rambut / hirsutisme

f. Galaktorea

g. Obesitas (BMI)

h. Riwayat operasi pelvis

i. Dismenorea / dispareuni

j. Tumor adneksa(Dewata, et all, 2008)

Perawatan kesuburan

a. Perawatan kesuburan rutin

Dalam banyak kasus, ketidaksuburan disebabkan oleh masalah yang jelas dan bisa diobati. Perawatan kesuburan mencakup:

1) Pengobatan kesuburan untuk meransang ovulasi

2) Perawatan hormonal untuk meransang produksi sperma

3) Pengobatan dengan corticosteroid untuk menekan produksi antibodi penghancur sperma

4) Operasi minor misalnya, untuk memperbaiki kerusakan pada saluran Falopi atau pada saluran reproduksi pria
5) Operasi-operasi lainnyamisalnya pengangkatan fibroid

b. Perawatan kesuburan buatan

Gangguan ovulasi adalah ovulasi yang tidak teratur setiap bulan, termasuk didalamnya oligoovulasi yang tidak tertur setiap bulan, termasuk didalamnya oligoovulasi dan anovulasi.Berdasarkan defenisi yang telah disepakati oligouvulasi adalah ovulasi yang terjadi setiap 35-180 hari, sedangkan anovulasi adalah tidak terjadinya ovulasi selama $\geq 6$ bulan berurutan.Gangguan ovulasi didapatkan pada kurang lebih 20-40 $\%$ wanita dengan infertilitas (Samsulhadi and Hendarto, 2009).

Pada wanita dengan pola haid teratur dengan panjang siklus menstruasi 28 hari, maka kemungkinan terjadi ovulasi adalah hari ke-14 menstruasi.Bagaimana pengaruh obesitas terhadap ovulasi?Pengaruh yang nyata adalah terhadap perkembangan kantung telur yang ada di ovarium (Misradiarly, 2007).

Walaupun fungsi hormon dapat berada dalam keadaan normal, gangguan pada ovarium dapat mempengaruhi ovulasi.misalnya, kista atau tumor ovarium, penyakit ovarium polikistik atau kerusakan ovarium akibat endometriosis atau riwayat pembedahan dapat mengganggu siklus ovarium sehingga mempengaruhi fertilitas. Pada akhirnya, fungsi ovulasi dapat dipengaruhi oleh wanita yang berat badannya berlebih ( Henderson and Jones, 2005).

Beberapa penelitian menyebutkan bahwa wanita usia reproduksi dengan Body Mass Indekx atau BMI lebih dari 25 dapat mengakibatkan terjadinya Polycystic Ovari (PCO).Sebagai gambaran 
sederhana adalah pola ovarium wanita dengan PCO terdapat banyak kantung telur, kecil-kecil dan terganggu pematangannya.Dengan demikian pada orang dengan PCO sering mengalami anovulasi atau tidak dapat 'bertelur' (Misradiarly, 2007). Jika pada wanita normal tanpa PCO hanya satu kantung telur yang mencapai besar yang optimal, maka pada wanita dengan PCO tidak didapatkan satu pun kantung telur yang memiliki besar yang optimal.Akibatnya telur yang ada di dalamnya tidak pernah matang dan gangguan hormon yang terjadi menyebabkan pula tidak dapat pecah (Misradiarly, 2007).

Jika pada seseorang wanita dengan BMI melebihi 28 ternyata masih dapat mengalami ovulasi dan setelah telur yang keluar berhasil dibuahi oleh spermatozoa suami kemudian terjadi embrio, maka gangguan yang mungkin muncul adalah kegagalan implantasi embrio hasil fertilisasi. Hal ini mungkin sangat terjadi pada proses bayi tabung (Misradiarly, 2007).

\section{KERANGKA KONSEP DAN DEFINISI OPERASIONAL}

Kerangka Konsep

Berdasarkan teori,diduga terdapat hubungan obesitas terhadap infertilitas, maka kerangka konsep penelitian dengan variabelindependen dan dependen sebagai berikut :

Variabel independen variable dependen

\begin{tabular}{|c|c|}
\hline Obesitas & Infertilitas \\
\hline
\end{tabular}

Definisi Operasional

$$
\text { Definisi operasional }
$$

digunakan sesuai dengan definisi konseptual dimana setiap pasien infertilitas dilakukan penilaian apakah termasuk dalam obesitas. Penilaian ini digambarkan dalam bentuk tabel, sebagai berikut:

Defenisi Operasional

\begin{tabular}{|c|c|c|c|c|c|}
\hline Varia & $\begin{array}{c}\text { Definisi } \\
\text { Operasional }\end{array}$ & Cara & $\overline{\text { Ala }}$ & Skala & Hasil \\
\hline $\begin{array}{l}\text { Obesi } \\
\text { tas }\end{array}$ & $\begin{array}{l}\text { berat badan lebih } \\
\text { dengan dasar nilai } \\
\text { Body Mass Index } \\
\text { ( BMI) } \\
\text { pada wanita PUS, } \\
\text { dihitung } \\
\text { berdasarkan } \\
\text { TB dan BB } \\
\text { PUS yang tercatat } \\
\text { di Rekam Medik }\end{array}$ & $\begin{array}{l}\text { Meng } \\
\text { hitung } \\
\text { BMI }\end{array}$ & $\begin{array}{l}\text { Daftar } \\
\text { Isian }\end{array}$ & $\begin{array}{l}\text { Nomi } \\
\text { nal }\end{array}$ & $\begin{array}{l}\text { Obesitas } \\
\text { ya : } \\
\text { BMI 30-39,9 } \\
\mathrm{kg} / \mathrm{m}^{2} \\
\text { Tidak } \\
\text { obesitas: } \\
\text { BMI 20-24 } \\
\mathrm{kg} / \mathrm{m}^{2}\end{array}$ \\
\hline $\begin{array}{l}\text { Inferti } \\
\text { litas }\end{array}$ & $\begin{array}{l}\text { Wanita PUS yang } \\
\text { telah didiagnosa } \\
\text { dokter dengan } \\
\text { infertilyang } \\
\text { tercatat di } \\
\text { Rekam Medik }\end{array}$ & $\begin{array}{l}\text { Studi } \\
\text { Doku } \\
\text { menta }\end{array}$ & $\begin{array}{l}\text { Daftar } \\
\text { Isian }\end{array}$ & $\begin{array}{l}\text { Nomi } \\
\text { nal }\end{array}$ & $\begin{array}{l}\text { Infertil: } \\
\text { Ya jika : } \\
\text { diagnose } \\
\text { dokter } \\
\text { infertil } \\
\text { Tidak: } \\
\text { diagnose } \\
\text { dokter tidak } \\
\text { infertil }\end{array}$ \\
\hline
\end{tabular}

Hipotesis

$\mathrm{Ha}$ : ada hubungan obesitas dengan infertilitas

\section{METODOLOGI PENELITIAN}

Jenis dan Desain Penelitian

Penelitian ini adalah penelitian kuantitatif ,desain korelasi dengan pendekatan cross sectional, untuk mengetahui hubungan obesitas dengan infertilitas pada wanita pasangan usia subur, dengan melakukan pengukuran pada variabel independen dan variabel dependen (Suyanto dan Salamah, 2009).

\section{Populasi dan Sampel}

Populasi pada penelitian ini adalah semua wanita Pasangan Usia Subur yang tercatat di Poliklinik Kebidanan RS Awal Bros Pekanbaru pada bulan Januari s/d Desember tahun 2013 yang berumur 20-35 tahun sebanyak 155 orang.

Sampel diambil dengan teknil sampel, total populasi yang berjumlah 155 orang .

\section{Pengolahan Data}

Berdasarkan data sekunder yang diperoleh dengan studi 
dokumentasi,dari registerpoliklinik kebidanan dan file/medical record pasien diklinik kebidanan RS .Awal Bros bulan januari s/d Desember 2013 , yaitu berupa identitas Pus, berat badan dan tinggi badan, di lakukan peng hitungan Indeks Masa Tubuh masing- masing wanita Pus yang tercatat.dan dilakuan pengolahan data dengan tahap editing, Coding , data Entry

\section{Analisis data}

Analisis data dilakukan secaraunivariat dan Bivariat

Jenis uji statistik yang digunakan adalah uji chi square, datanya berbentuk nominal dan sampelnya besar $(n>25)$. Cara perhitungan dengan bantuan tabel kontingensi $2 \times$ 2 sebagai berikut:

\begin{tabular}{|c|c|c|c|}
\multicolumn{4}{|c|}{ Tabel Chi Square } \\
\cline { 2 - 3 } & $\mathrm{Ya}$ & Tidak & $\begin{array}{c}\text { Jumlah } \\
\text { sampel }\end{array}$ \\
\hline $\begin{array}{c}\text { Infertilitas } \\
\text { Obesitas }\end{array}$ & $\mathrm{A}$ & $\mathrm{B}$ & $\mathrm{a}+\mathrm{b}$ \\
\hline $\begin{array}{c}\text { Tidak } \\
\text { obesitas }\end{array}$ & $\mathrm{C}$ & $\mathrm{D}$ & $\mathrm{c}+\mathrm{d}$ \\
\hline Jumlah & $\mathrm{a}+\mathrm{c}$ & $\mathrm{b}+\mathrm{d}$ & $\mathrm{a}+\mathrm{b}+\mathrm{c}+\mathrm{d}$ \\
\hline
\end{tabular}

(Suyanto dan Salamah, 2009)

Berdasarkan tabel kontingensi di atas disusun rumus sebagai berikut

$$
\begin{aligned}
& X^{2}=n(|a d-b c|-1 / 2 n)^{2} \\
& (a+b) \frac{(a+c)(b+d)(c+d)}{(a+d) ~}
\end{aligned}
$$

$$
\text { df }=1, \text { Nilai alfa } 5 \%=0,05
$$

Penelitian ini menggunakan uji hipotesis untuk mengetahui ada, hubungan obesitas dengan infertilitas.

$$
\begin{gathered}
\text { Jika }: X^{2} \text { hitung }>X^{2} \text { tabel }=\text { Ada } \\
\text { hubungan } \\
\mathrm{X}^{2} \text { hitung }<\mathrm{X}^{2} \text { tabel }=\text { Tidak } \\
\text { ada hubungan }
\end{gathered}
$$

\section{HASIL DAN PEMBAHASAN}

\section{Hasil Penelitian}

Hasil penelitian sebagai berikut

\section{Analisis Univariat}

a. Berdasarkan diagram 5.1 didapatkan bahwa wanita pasangan usia subur yang mengalami obesitas Di Rumah Sakit Awal Bros sejumlah 105 orang $(67,74 \%)$ dan yang tidak mengalami obesitas sejumlah 50 orang $(32,26 \%)$.

\section{Diagram 5.1}

Distribusi Frekuensi Wanita

Pasangan Usia Subur Yang Mengalami Obesitas di Rumah Sakit Awal Bros Tahun 2010

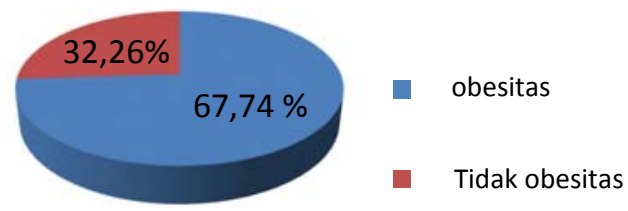

b.Distribusi Frekuensi wanita yang mengalami infertilitas di Rumah Sakit Awal Bros

\section{Diagram 5.2}

Distribusi Frekuensi Wanita

Pasangan Usia Subur obesitas yang mengalami Infertilitas di Rumah

Sakit Awal Bros Tahun 2010

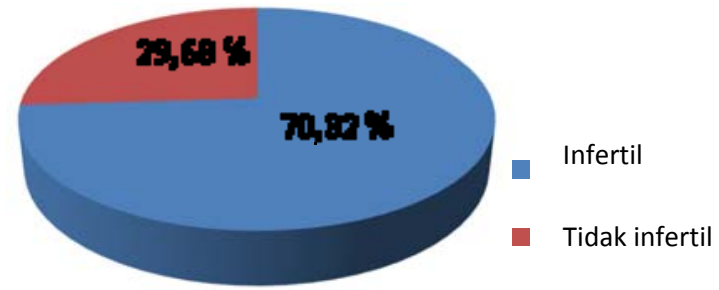

Berdasarkan diagram 5.2 diatas didapatkan bahwa Wanita pasangan usia subur yang mengalami infertil sejumlah 109 orang $(70.32 \%)$ dan yang tidak mengalami Infertil sejumlah 46 orang $(29,68 \%$ 


\section{Analisis Bivariat.}

Analisis bivariat untuk melihat hubungan obesitasdengan infertilitas pada wanita pasangan usia subur

Tabel 5.1

Hubungan Obesitas Dengan Infertilitas Pada Wanita Pasangan Usia Subur Di Rumah Sakit Awal Bros PekanbaruTahun 2010

\begin{tabular}{|c|c|c|c|c|c|c|}
\hline \multirow{3}{*}{ Obesitas } & \multicolumn{4}{|c|}{ Infertilitas } & \multirow[b]{3}{*}{ Jumlah } & \multirow{3}{*}{$\begin{array}{c}\mathrm{X}^{2} \text { tabel= } \\
3.84 \\
\mathrm{X}^{2} \text { hitung= } \\
16,07 \\
\mathrm{df}=1 \\
\alpha=0,05\end{array}$} \\
\hline & \multicolumn{2}{|c|}{$\mathrm{Ya}$} & \multicolumn{2}{|c|}{ Tidak } & & \\
\hline & Frek & $\%$ & Frek & $\%$ & & \\
\hline $\mathrm{Ya}$ & 85 & 80,95 & 20 & 19,05 & 105 & \\
\hline Tidak & 24 & 48 & 26 & 52 & 50 & \\
\hline $\mathrm{jml}$ & 109 & & 46 & & 155 & \\
\hline
\end{tabular}


Pada tabel 5.1 : dari 105 wanita pasangan usia subur yang obesitas, 85 orang $(80,95 \%)$. mengalami infertilitas Hsil penelitian ini adalah $X^{2}$ hitung $>X^{2}$ tabel, dimana $X^{2}$ hitung 16,07 dan $X^{2}$ tabel 3, 84 maka hipotesa nol ditolak. Artinya ada hubungan antara obesitas dengan infertilitas pada wanita pasangan usia subur.

Hasil penelitian ini adalah $X^{2}$ hitung $>X^{2}$ tabel, dimana $X^{2}$ hitung 16,07 dan $X^{2}$ tabel 3, 84 maka hipotesa nol ditolak. Artinya ada hubungan antara obesitas dengan infertilitas pada wanita pasangan usia subur

\section{PEMBAHASAN}

Hasil penelitian ini didapatkan bahwa obesitas pada wanitapasangan usia subur sejumlah 105 orang $(67,74 \%)$ dan tidak obesitas sejumlah 50 orang $(32,26 \%)$

Menurut Charlish and Davies (2005), Penelitian menunjukkan bahwa wanita dengan berat badan lebih mungkin akan sulit hamil. Semua risiko kesehatan yang dihubungkan dengan kelebihan berat badan bisa mengganggu proses pembuahan, kehamilan, dan kelahiran. Seorang isteri yang mengalami obesitas sangat mungkin mendapatkan problem gangguan ovulasi dan gangguan implantasi embrio (Misradiarly, 2007). Hasil penelitian ini sesuai dengan teori yang dikemukakan oleh Charlish dan Davies bahwa kelebihan berat badan dapat mengganggu proses pembuahan dan akan terjadi gangguan pada ovulasi.

Fungsi hormon dapat berada dalam keadaan normal, gangguan pada ovarium dapat mempengaruhi ovulasi. Misalnya, kista atau tumor ovarium, penyakit ovarium polikistik atau kerusakan ovarium akibat endometriosis atau riwayat pembedahan dapat mengganggu siklus ovarium sehingga mempengaruhi fertilitas.( Misradiarly, 2007) Hasil penelitian ini tidak sejalan dengan pendapat diatas , karena perempuan pasangan usia subur pada penelitian ini tidak mengalami gangguan fungsi hormone, hal ini kemugkinan karena tidak dilakukan penelitian tentang hormone yang dapat menyeakan infertilitas. Wanita pasangan usia subur sebaiknya mengatur pola makan, supaya dapat menurunkan berat badan dan ovulasi akan berlangsung dengan normal.

Pada penelitian ini terdapat hubungan antara obesitas dengan terjadinya infertilitas. Derajat kebebasan( df ) yang di gunakan adalah 1 dengan tabelchi-square, adalah 3,84. Dari hasil penelitian didapatkan terbukti $x^{2}$ hitung $>x^{2}$ tabel, di mana $x^{2}$ hitung 16.07 dan $x^{2}$ tabel 3,84 maka terdapat hubungan antara obesitas dengan infertilitas pada wanita pasangan usia subur

Menurut Charlish and Davies (2005), penelitian menunjukan wanita dengan berat badan lebih mungkin akan sulit hamil. Semua resiko kesehatan yang di hubungkan dengan kelebihan berat badan bisa mengganggu proses pembuahan, kehamilan, dan kelahiran.

Hasil Penelitian ini di dukung oleh penelitian yang di publikasikan di Journal Of Clinical Endocrinology dan Metabolism (JCEM) 2009, telah lama menemukan hubungan antara kedua factor tersebut. Study ini melibatkan 96 perempuan. Mereka dibagi secara seimbang kedalam tiga kelompok sesuai dengan Body Massa Indeks (Robker, et al 2009).

Penelitian menunjukan bahwa wanita dengan berat badan lebih, akan sulit hamil bisa mengganggu proses pembuahan, kehamilan, dan kelahiran (Charlish and Davies, 2005)

\section{KESIMPULAN DAN SARAN KESIMPULAN}

Berdasarkan penelitian ini dapat disimpulkan bahwa:

1. Wanita pasangan usia subur yang mengalami obesitas 105 orang $(67,74 \%)$ dan tidak obesitas sebanyak 50 oramg $(32,25 \%)$. 
2. Wanita pasangan usia subur yang mengalami Infertil sebanyak 109 orang $(70,32 \%)$ dan tidak Infertil 46 $(29,67 \%)$.

3. Hubungan obesitas dengan Infertilitas padawanita pasangan usia subur di dapatkan hasil dimana wanita pasangan usia subur yang obesitas dan mengalami infertile sebanyak 85 oramg $(80,95 \%)$. Wanita pasangan usia subur yang tidak obesitas dan tidak mengalami infertile sebanyak 20 orang (19,04\%). Wanita pasangan usia subur yang tidak obesitas dan mengalami infertile sebanyak 24 orang (48\%). Wanita pasangan usia subur yang tidak obesitas dan tidak mengalami infertil sebanyak 26 orang (52\%).

Berdasarkan uji chisquare di dapatkan hasil yaitu $x^{2}$ hitung $>x^{2}$ tabel $=16,07>3,84$ maka hipotesa nol di tolak sehingga terdapat hubungan antara obesitas dengan infertilitas pada wanita pasangan usia subur .

\section{SARAN}

Hasil penelitian ini dapat menjadi masukan bagi pembaca tentang wanita pasangan usia subur yang obesitas cenderung mengalami infertilitas.

\section{DAFTAR PUSTAKA}

Benson, R.C. dan Pernoll, M.L. 2009.Buku Saku Obstetric \& Ginekologi.Jakarta, Penerbit Buku Kedokteran EGC

Charlish, A dan Davies,K. 2005. Meningkatkan Kesuburan Untuk Kehamilan Alami. Jakarta, Erlangga

Depkes.RI, 2009. Aktifitas Fisik dan Diet SeimbangMencegah Kanker.www.Depkes.or.id. 20 maret 2009

Dewata, L, Samsulhadi, Soehartono,.Sukaputra, B, Pramono, H, Waspodo, D. dan Hendarto, H. 2008.Pedoman
Diagnosis Dan Terapi Bag/Smf Ilmu Kebidanan Dan Penyakit Kandungan. Surabaya, Rumah Sakit Umum Dokter Soetomo

Fraser, D.M dan Cooper, M.A. 2009.Myles Buku Ajar Bidan Edisi 14.Jakarta, Penerbit Buku Kedokteran EGC

Henderson, C dan Jones, K. 2005.Buku Ajar Konsep Kebidanan. Jakarta, Penerbit Buku Kedokteran ECG

Khomsan, A. 2004.Pangan dan Gizi untuk Kesehatan. Jakarta, PT Raja Grafindo Persada

Manuaba, I.B.G. 2004.Penuntun Kepaniteraan Klinik Obstetri dan Ginekologi, E/2. Jakarta, Penerbit Buku Kedokteran ECG)

Misnadirly. 2007. Obesitas sebagai Factor Risiko Beberapa Penyakit. Jakarta, Pustaka Obor Popular

Norwitz, E.R. dan Schorge, J.O. 2006.Obstetric dan Ginekologi Edisi Kedua. Jakarta, Erlangga

Prawirohardjo, S. 2007. Ilmu Kandungan. Jakarta, Tridasa Printer

Robker, L.R, Lisa K.A,.Btenton D.B, Penny, N.T, Lindsay, R.C, Darryl, L.R, Michelle, L, and Robert, J.N.1999.Obese Women Exhibit Differences in Ovarian Metabolites, Hormones, and Gene Expression Compared with Moderate-Weight Women. The journal of Clinical Endocrinology \& Metabolism Vol. 94, No. 55 1533-1540. 